\title{
Mining Foreign Language Teaching Manuals for the History of Pragmatics
}

Nicola McLelland, University of Nottingham (nicola.mclelland@nottingham.ac.uk)

\section{Abstract}

Foreign language learning manuals can be valuable sources for the history of pragmatics and historical pragmatics. They may contain explicit guidance on pragmatics not found in nativespeaker grammars: for example, accounts of German forms of address in seventeenth and eighteenth-century English-German manuals provide evidence of changing views on the appropriateness of $i h r$ and Sie earlier than does the "native" grammatical tradition. The bilingual model dialogues typical of such manuals may also implicitly model appropriate linguistic behaviour, demonstrated here by examining the communicative genre of bargaining in a series of three related English-Dutch language manuals of the seventeenth and eighteenth centuries. Furthermore, the dialogues may provide metalinguistic comment on linguistic behaviour, for example criticizing the culture of excessive negative politeness. Such sources can enrich our knowledge of language use and attitudes to language use in the area of politeness, complementing the evidence to be gleaned from mainstream native grammars, civility manuals, merchants' guides, and the like.

Keywords: Historical pragmatics; history of pragmatics; Dutch; German; language learning manuals; forms of address; politeness

\section{Introduction}

In the growing field of historical pragmatics there have so far been two main ways of accessing relevant data about the spoken language, direct and indirect. One direct way is to induce generalizations about pragmatic rules of the past from texts from the past. Here corpus linguistics can provide qualitative and quantitative data (see for example Whitt 2015 on the encoding of evidentiality in Early Modern German, drawing on the GerManC corpus); we may also benefit from approaches such as Historical Dialogue Analysis, a multidisciplinary approach to analysing dialogues in the past, in order to make inferences about rules governing conversation in the past, with the usual caution when analysing written representations of oral discourse (cf. Jucker et al. 1999, and the series founded by Nine Miedema and colleagues, whose first volume is concerned with the historical analysis of 
dialogues in medieval epics: see Unzeitig et al. 2011). Alternatively, we can rely not directly on evidence of language in use, but on indirect, metalinguistic evidence, in which case historical pragmatics may overlap with the history of pragmatics within the wider history of linguistic thought - see, in Gardt's history of linguistics in Germany, his discussion of Kommunikationskultur in seventeenth and eighteenth-century Germany, with the emphasis on reflections on language in use found in guides to letter-writing, titularies, rhetorics, and the like, sources which may be of particular relevance for the history of politeness (Gardt 1999: 158-171; see also Till 2004, esp. pp. 111-196). Angelika Linke's work on communicative genres in bourgeois nineteenth-century Germany provides another approach to this kind of analysis, albeit from a different theoretical perspective (Linke 1996, 1998, 2007). Within Dutch language history, Van der Wal's 1992 language history is, in essence, a history of language standardization, and Rutten \& Vosters (2011) still more or less equate linguistic norms with spelling norms. Recent years have, however, seen work on the history of politeness in Dutch, including the work of Marcel Bax and his colleagues (Bax 2001, Bax \& Streekstra 2003, and a special issue of this journal, Bax \& Kádár 2011).

Against this background, I argue here for the value of an additional kind of source that has so far received scant attention in historical pragmatics and the history of pragmatics: foreign language learning manuals, a genre now receiving increasing attention in language history and in the history of education. ${ }^{1}$ There is a long tradition, at least from the fifteenth century, of language learning manuals to help Europeans to learn each others' languages (see, for the Dutch and German contexts, Loonen 1991, Noordegraaf \& Vonk 1993, Klippel 1994, McLelland 2004, Glück 2002, 2013). Typically, such language manuals consisted of a grammar (or, in the earliest versions, sample forms or sentences from which patterns could be induced) and a number of model dialogues, usually bilingual, with the two languages presented in parallel columns. Recent studies have begun to show the importance of such foreign language grammars for understanding how the language structures of vernacular languages were understood in late medieval and early modern times (e.g. Langer 2004, McLelland 2008). There has also been some work on the representations of the "target" culture in early foreign language textbooks (e.g. Van der Lubbe 2008, Guthke 2011). This paper will examine these materials as some of the earliest surviving materials that give an

\footnotetext{
${ }^{1}$ For an overview of the state of research in the history of language teaching in Europe, see the special issue of Language \& History 57.1, ed. McLelland \& Smith (2014).
} 
insight into the historical pragmatics of Dutch and German, and the history of presenting implicitly or explicitly - pragmatic rules. For, as we might expect, the dialogues contained in these language manuals are interesting because they do not just model language forms for the learner to copy, but also the correct use of those forms in context, i.e. the relationship between form and function.

Before embarking on the analysis, it is important to note the methodological risks inherent in using foreign language manuals as sources. One fundamental difficulty applies to any kind of historical text that we seek to use as evidence of oral language use, whether it be the dialogue of dramas and narrative prose, the language of sermons, or the language of newspapers, for example: ${ }^{2}$ the evidence that we have is indirect. We must hope either that written texts preserve some of the features of spoken language, or, in the case of dialogues, that their authors are reasonably successful mimics of "real" conversation, at least with regard to those features that we seek to analyse. Other problems, however, are more specific to foreign language learning manuals. First, we are faced with constructed language which, although we may assume it is intended to mimic "real" conversation for the benefit of learners, nevertheless also simplifies the nature of conversation. False starts and interruptions are rare, for example; turn-taking seldom, if ever, needs to be negotiated. Equally, while conversations may sound relatively naturalistic (e.g. with frequent modal particles in Dutch and German), they may also exaggerate the features of a communicative genre (such as bargaining, discussed below), in order to illustrate the use of certain structures, vocabulary and functions chosen by the authors. ${ }^{3}$ This is not, necessarily, so problematic - it is perhaps no worse, say, than the practice, in other branches of linguistics, of analysing language elicited from subjects asked to perform certain tasks in response to given stimuli, modelled on real-life but nonetheless constructed in an artificial context. However, it needs to be borne in mind.

Another potential problem is the bilingual nature of the model dialogues: it can be difficult to be sure whether the language on both sides of the language pair would have passed as a good

\footnotetext{
2 The documentation of the Early Modern German corpus distinguishes, somewhat problematically in my view, between the genres drama, newspapers, sermons, personal letters and journals as "orally oriented", and academic, medical and legal texts, intended to represent more print-oriented registers. See http://www.llc.manchester.ac.uk/research/projects/germanc/.

${ }^{3}$ For example, alternative phrasings may be given in a single "turn". See Table 2 below, where the seller's words in 6.iv. of Table 2 below, I am able to sell it as cheap as any other man, as any in the City, where as any other man, and as any in the City are probably to be read as two alternative formulations for the same context.
} 
imitation of the spoken language of the time. Some authors are likely to have been less competent in one language and culture than another, resulting not just in constructed language, but potentially in language that is badly constructed - even if not ungrammatical, possibly unnatural to a contemporary native-speaking member of the speech community. The risk is reduced when we have external evidence that the authors were competent bilinguals a case in point is William/Willem Sewel (1653-1720), discussed below, a Dutch author of English background who also spent ten months in England, who produced both a grammar of Dutch and a manual of English for the Dutch, in addition to a bilingual dictionary (Sewel 1705, 1708a, 1708b; see Salmon 1992: 135, Scheurweghs 1960; Hall 2004). But we cannot assume that every author was as well-qualified as Sewel. ${ }^{4}$

An additional, related, complication is that material was endlessly recycled. Whole manuals could be adapted to new language pairs. To give just two examples, Sewel's guide to English for Dutch (1705) was reworked by Matthias Kramer (1746) for the German market (Klippel 1994: 67, 71); ${ }^{5}$ Giovanni Veneroni's Maître italien (1678) for teaching Italian to the French was repurposed not just to teach Italian to the English (Courville 1728) but also to teach French to Spanish speakers (Veneroni \& Uvedale 1728; Bruña Cuevas 2014). So many dialogues and manuals attributed to the Antwerp language teacher Noel de Berlaimont (d. 1531) circulated, in so many language combinations, from the sixteenth century onwards, that his name gave rise to a genre, the Parlament (Hüllen 2005: 55-57). Even within language pairs, dialogues were often recycled from one manual to later ones, so that an "original" text or author is difficult or impossible to identify. A traceable example of such a recycled dialogue in the German tradition is that "Between a German learning English and his master of languages", published in a manual of German for English learners (Beiler 1731: 283-288), but first published a few years early in an English grammar for German learners, Thomas Lediard's Grammatica Anglicana Critica (1725). However, an untraceable line of descent seems to lie behind dialogues modelling exchanges with a draper, extending from $15^{\text {th }}$ century European manuals (see Section 3.1 below) right up to $20^{\text {th }}$-century manuals of

\footnotetext{
${ }^{4}$ Sewel's use of the form swimmed for swam (Sewel 1706: 256) might suggest an imperfect mastery of English, but swim was attested as a weak verb in English, dialectally at least until the $18^{\text {th }}$ century (Oxford English Dictionary online, s.v. swim). See Loonen (1991: 336-342) for a compilation of what we know about English teachers in the Low Countries in the period 1500-1800.

${ }^{5}$ See also Loonen (1991: 180-184) for examples of borrowing between English language learning materials in the Low Countries.
} 
Mandarin (Williamson 1947; see McLelland 2015a), and although it would be impossible to trace a clear line of descent between these two examples, they (and the many similar dialogues that one could readily identify over the centuries in between, inlcuding those discussed below) give an indication of the wide circulation within European language learning traditions of highly similar dialogues dealing with prototypical scenarios. A final important caveat is that we cannot be sure, when material is recycled years later more or less verbatim, that the language described in the grammar or modelled in its dialogues still reflects current usage - certainly, sometimes dialogues are updated, but sometimes clearly outdated material is cynically reprinted for commerical gain. ${ }^{6}$ In some cases, however, we can turn the recycling of dialogues across the years to our advantage, for when authors (or compilers) do take the trouble to update them, they may provide useful evidence of changes in language forms and/or language use, as I will tentatively suggest in Section 3.2 below.

With those caveats in place, this paper presents two case studies of the kinds of ways in which foreign language learning materials can be valuable sources for the history of linguistics: first, in what they state explicitly about pragmatic rules, here taking forms of address in German as an example (Section 2), and second, in the conversations they model, (Section 3). In Section 3, I will draw on two theoretical approaches to examine the model conversations: the notion of the communicative genre, as used by Linke (2007) in her study of nineteenth-century German bourgeous culture (including, for example, paying a call); and the notion of negative politeness (Brown \& Levinson 1987; see also Culpeper 2009). My examples are taken from German-English manuals and Dutch-English language manuals of the seventeenth and eighteenth centuries, ${ }^{7}$ but they are intended to illustrate the potential of these sources for the historical pragmatics of European (and probably non-European) languages more widely.

\section{Case study 1: Forms of address in German}

We already know that grammars and language manuals for non-native learners can be valuable sources in the history of linguistics and language history (see Langer 2002,

\footnotetext{
${ }^{6}$ An example is the Mandarin Chinese of Williamson's Teach Yourself Chinese (1947), which, when reprinted in 1979, still modelled the language of a pre-revolutionary China long gone. See McLelland 2015a.

${ }^{7}$ On the history of German manuals for English speakers, see McLelland 2015b and references there. On the history of Dutch-English manuals, and Dutch for English speakers, see Scheeurweghs (1960), Loonen (1991), Salverda (2004), and Verbaan \& Vismans (2010).
} 
McLelland 2008), because they may include codifications of some aspects of the language before "native" grammarians do, or in greater detail, because they have to make explicit to learners the unwritten rules by which proficient native speakers operate. For example, McLelland (2008) demonstrated that seventeenth-century grammars of German for foreign learners were more alert to the problems of German word order and were more innovative in trying to describe them than was the native grammatical tradition of the time, and it seems likely that mainstream "native" grammars later drew on these foreign-language grammars. But the same can also be said with regard to pragmatics: once again, materials aimed at nonnative speakers pay attention to matters that are not necessarily of interest to native-speaker grammars, ${ }^{8}$ as we shall see be examining the presentation of German forms of address in early modern manuals for English speakers.

Today's German has three second-person pronouns $d u$, ihr and Sie. The distinction between $d u$ and $i h r$ is one of number, between singular and plural; ${ }^{9}$ the polite form Sie (historically, a third person plural, and morphologically identical with it, except for capitalization of the polite you forms) may be used to singular or plural addressees. However, in medieval German, ihr was the usual polite form, singular and plural; Sie had not yet emerged. The early modern period sees the shift from this two-way system of the language to the current three-way system, going through a lengthy period where $i h r$ and Sie both functioned as polite forms, alongside other alternative polite forms, their uses variously differentiated (as we shall see below). Not only did the conventions governing forms of address change in the early modern and Enlightenment periods, ${ }^{10}$ but the whole matter also became ideologically charged, given the influence of French manners (politesse) on the rest of Europe and later

\footnotetext{
${ }^{8}$ They may be dealt with other kinds of guides for native speakers, however: in civility manuals, epistolaries and the like, a point to which I return in Section 4.

${ }^{9}$ In fact, although ihr is usually described in grammars, for native- and non-native speakers alike, as the plural for a group whom one would address individually as $d u$, it has long been observed that it can be used to any group "to stress plurality, even if all would normally be addressed individually as Sie". It may serve as a "neutral compromise" to mask uncertainty about whether to use $d u$ or Sie (Durrell 2002: 54).

${ }^{10}$ On the history of forms of address in German, and in comparison with other countries, see Besch (1996), Glück (2006), Polenz (1999: 60-61, 383-387) and further references there.
} 
criticism of such perceived artifice, in the context of Enlightenment preferences for 'natural' communication over 'artificial or 'affected' style. ${ }^{11}$

The earliest statement by a grammarian about the pragmatic rules of address that I know of is found in the very first grammar of German for English speakers, the High Dutch Minerva of Martin Aedler, a native German who moved to England, where he wrote his grammar (Aedler 1680). Although not a member of the Fruchtbringende Gesellschaft or 'Fruitbearing Society', the most important German language society of the time, Aedler had connections with it (Van der Lubbe 2007: 58-68); and his grammar shows the clear influence of the first ever comprehensive grammar of German, produced by one of the Society's prominent members, Justus Georg Schottelius (Schottelius 1663; see McLelland 2011: 245-249). Aedler's credentials as an authority on the German language were, then, impeccable. However, he did not follow Schottelius slavishly, and in the area of forms of address, he went well beyond Schottelius, who had said nothing whatever about how the different pronouns forms were to be used. Aedler (1680: 169) specified the pragmatic rules governing the three German second-person pronouns $d u$, ihr and Sie as follows:

Children and our own servants, as well as beasts: second person singular [i.e. $d u$ ]; for the servants of others, and other common sort of people as peasants and tradesmen are $2^{\text {nd }}$ ps. Pl [i.e. $i h r$; to a Gentleman or Gentlewoman and upwards, in the third person singular, and a magistrate of authority (though a single person) in the third person plural [i.e. Sie]

Perhaps for the very first time in a German grammar, Aedler's explanation tackled the relationship between grammatical form and pragmatic function in the pronoun system, because it needed to be explained to non-native speakers. Aedler spelled out explicitly the circumstances under which grammatically plural forms might serve the function of addressing a single interlocutor; and when third person forms might be used to address someone in the second person. His account is far more informative than those found in the 'native' German grammatical tradition of the same time. Both Aedler's most immediate predecessor and influence, Schottelius (1663), and, a decade after Aedler, Kaspar Stieler (1691: 118-119) offered a purely grammatical account of singular and plural, first, second and third person. A

\footnotetext{
11 On politesse see Losfeld (2011) and the review by Turcot (2011); on discussions of natural or artificial style in German rhetorics, see Till (2004).
} 
half-century later, Beiler's New German Grammar (Beiler 1731: 69) provided a very similar specification to Aedler's: the descriptions differ slightly, but the perceived hierarchy is the same: $i h r$ should be used "to common Servants, and mean people independent of us"; the third person singular is used "in speaking to our equals", and the third person plural "to Superiors, Nobles, and Princes". The potential for $d u$ to be deliberately offensive is also noted: it may be used "to any one, to whom we would shew Contempt o[r] Anger". ${ }^{12}$

By the middle of the eighteenth century, German grammars for native speakers were also attending to forms of address. Table 1 presents Gottsched's account in his grammar of 1748, as summarized by Polenz (1999: 384); note the characterization of the new third person plural Sie form of address as überhöflich, "overly polite". Gebhard Wendeborn, Minister for the German chapel on Ludgate Hill in London, was also an active teacher of German and successful publisher of German language learning materials; he used Gottsched's grammar as a basis for his Elements of German grammar (1774) for English speakers (see Carr 1935). His observation that the "plain and simple" system of address that had existed in Latin and Greek had now yielded to a tendency of "an affected politeness", with the third person being used as a form of address (Wendeborn 1774: 34), seems to share with Gottsched the typical Enlightenment impatience with the insincerity of affected politeness. ${ }^{13}$ Adelung's influential grammar of 1782 still listed the same four options given by Gottsched (1748) (plus a fifth, using a demonstrative Dieselben or titles such as Ew. Exzellenz). Polenz (1999: 183), following Besch (1996: 92) suggests that in Adelung's account we can "find hints of" (andeutungsweise ablesen) the emergence of a system which only became firmly established in Germany in the nineteenth century, today's two-way choice between polite Sie on the one hand and informal $d u(\mathrm{sg}$.$) and i h r(\mathrm{pl}$.) on the other.

\begin{tabular}{|l|l|l|}
\hline$D u$ & $\begin{array}{l}\text { 'you', second person } \\
\text { singular, informal }\end{array}$ & natürlich 'natural' \\
\hline ihr & $\begin{array}{l}\text { 'you', second person } \\
\text { plural, informal }\end{array}$ & althöflich 'old-style polite' \\
\hline $\begin{array}{l}\text { er or sie } \\
\text { singular }\end{array}$ & $\begin{array}{l}\text { 'he' or 'she', third person } \\
\text { singular }\end{array}$ & mittelhöflich 'medium polite' \\
\hline Sie & $\begin{array}{l}\text { 'they', third person plural } \\
\text { [capitalized] }\end{array}$ & $\begin{array}{l}\text { neuhöflich 'new-style polite' and überhöflich } \\
\text { 'overly polite' }\end{array}$ \\
\hline
\end{tabular}

\footnotetext{
12 The text has "Contempt of Anger", but I have assumed that "of" is an error for "or".

${ }^{13}$ On the concomitant changing status of politeness in rhetorical theory of the $18^{\text {th }}$ century, see Till (2004).
} 


\section{Table 1: Forms of address according to Gottsched (1748) (as summarized by Polenz} 1999: 384)

Yet evidence from grammars of German for English learners suggests that both Gottsched and Adelung were somewhat conservative in their accounts, presenting a system that already appeared dated to some speakers at least; today's $d u / i h r$ vs. Sie system may well have been further advanced than we have hitherto realized. Virtually contemporary with Gottsched (1748), John Bachmair's grammar of German for English learners (1751), although it made the same four-way distinction as Gottsched had ( $d u$; ihr; er or sie; and Sie), did not share Gottsched's disdain for the "new" polite form Sie as "overly" polite. Rather, Bachmair already presented Sie as the normal polite form: "In the polite Way of writing and speaking we use always the third Person of the Plural, sie, they, but the Meaning is you" [sic: Sie is not capitalized] (Bachmair 1751; 1771 ed.: 53). ${ }^{14}$ Whereas Gottsched stigmatized the new form Sie as "overly" polite, Bachmair even appears implicitly to stigmatize Gottsched's preferred unmarked polite form, the third person singular er/sie form, because of its pragmatic and grammatical ambiguity. First, it could be used between equals of lower station, but also from a superior to an inferior:

3. Common Trade, People speaking to each other make use of the third Person of the Singular, er, he, to a Man; and sie, she, to a Woman; yet the Meaning is you. This is also done by great People speaking to any Person of a much inferior Station.

Second, Bachmair pointed out, according to context, Er ist mein Freund could mean either 'he is my friend' or 'you are my friend' (Bachmair 1771: 53).

We have already seen that Wendeborn (1774) presented the same system as Gottsched and regretted the emergence of "an affected politeness" (Wendeborn 1774: 34). Yet he also already stated that addressing "a person of distinction in the plural number of the third person" - which Polenz (1999: 183) implies was only established in the $19^{\text {th }}$ century - was already the

\footnotetext{
${ }^{14}$ The full account reads: "1. Husbands and Wives, Parents to their Children, Brothers and Sisters, or very good Friends, by way of Familiarity, make use of the second Person singular; $d u$, thou [...]; 2. To Servants, and the meaner sort of people, we say $i h r[\ldots]$; 3. Common Trade, People speaking to each other make use of the third Person of the Singular, er, he, to a Man; and sie, she, to a Woman; yet the Meaning is you. This is also done by great People speaking to any Person of a much inferior Station. [...]; 4. In the polite Way of writing and speaking we use always the third Person of the Plural, sie, they, but the Meaning is you; 5. Yet $d u$ and $i h r$ are used in Poetry and from the Pulpit; $d u$ for the Singular, or to one Person; $i h r$ for the Plural, or to many Persons."
} 
"prevailing custom", as in "Wie befinden sie [sic] sich? How do THEY do? instead of, Wie befindet ihr euch? How do YOU do?" (Wendeborn 1774: 34). Wendeborn also already viewed the use of $I h r$ to address someone in the singular as a "singular [i.e. odd] way of speaking", though it was, he says, common in the time of Charles V [i.e. 1519-1556] (Wendeborn 1774: 34). ${ }^{15}$ Thus, at least two authorities on German for English speakers predating Adelung (1782) already presented the Sie plural polite form either as the form "always" used or as the "prevailing custom".

This small case study shows that grammars for foreign learners can provide additional metalinguistic evidence for attitudes to language change. In this case, the presentation to English learners of the pragmatics of German forms of address in the eighteenth Century reveals a somewhat difference picture to that presented by the native grammatical tradition and mainstream language histories, one that allows us to see evidence of changes before they become visible in the native-speaker grammatical tradition.

\section{Model conversations}

Having given an example of how examining the explicit rule-giving in language learning manuals can enrich our understanding of the history and historiography of pragmatics, I shall now illustrate what the model conversations in such manuals can tell us. Radtke (1994) already used seventeenth-century manuals of French as a foreign language to reconstruct the spoken language of the period, though from a Conversation Analysis perspective; I am not aware that anything similar has been tried previously for the Germanic languages. My examples come from three related Dutch-English language learning manuals of the seventeenth and eighteenth centuries $(1664,1706,1788)$, chosen because they allow us to chart changes over time in otherwise very similar materials. I consider first the communicative genre of agreeing a price (3.1). Dialogues on agreeing a price are ubiquitous in language manuals in early modern Europe - it is telling that Loonen's study of EnglishDutch manuals between 1500 and 1800 is entitled For to learne to buye and sell (Loonen 1991); Radtke (1994: 151-237) also chose the situation as a case study in his history of

\footnotetext{
${ }^{15}$ For Crabb (1800: 99-100) - who followed and adapted Adelung for English learners - it was "not uncommon to use $i h r$ to tradesmen", and er/sie to male or female domestics; sie (i.e. Sie) was "usual" in addressing "your equals and superiors". Since Crabb was not, however, a native speaker of German as far as we know, and the full title described his grammar as "a translation from Adelung", his evidence is of lesser weight.
} 
spoken French. ${ }^{16}$ The analysis here thus invites future comparison with similar analysis for other language pairs. Second, I consider negative politeness between a host and his guest (3.2), in order to complement the more straightforward case of polite forms of address in Section 2, in a period where notions of politeness (and excessive politeness) were changing.

\subsection{Case study 2: Agreeing a price as a communicative genre}

A communicative genre is "marked by fixed linguistic patterns, whose function is to indicate the socio-cultural significance of an action", according to Linke (2007: 475), with reference to Günther \& Knoblauch (1995: 6), who state that

communicative genres may be seen as taking the burden away from the actors, relieving them ("Entlastung") of having to co-ordinate every communicative action anew. By way of routinization these interactive tasks become 'non-problematic' and speakers may concentrate on other tasks. Genres are generated as soon as communicative interactants are faced with recurring problems which are of great relevance to the actors. [...] Functionally, communicative genres can be defined as historically and culturally specific, pre-patterned and complex solutions to recurrent communicative problems. (Günther \& Knoblauch 1995: 8).

The conversations that I examine below are not primary sources for conversation analysis, for which Günther originally developed the notion of the communicative genre; they are are several steps removed from the reality of spoken language. However, they are primary sources for the historian of language education and linguistic historiography, and it is as such that I shall treat them. ${ }^{17}$

The communicative genre of negotiating a price is an extremely consistent feature of language manuals from the late middle Ages onwards. The earliest surviving example is found in a German-Italian manuscript aimed at cloth merchants. ${ }^{18}$ By the fifteenth century at

\footnotetext{
${ }^{16}$ The first Dutch-English (or Flemish-English) manual was published by Heunrdricx in Antwerp in 1576, according to Salmon (1992: 136); see also Loonen (1991). On Hillenius see Scheurweghs (1960), Vorlat (1969), and Salmon (1992). On Sewel, see also Scheurweghs (1960) and Hall (2004). Loonen has no information on Teissier, nor have I been able to glean any myself.

${ }^{17}$ Linke (2007) provides a precedent for applying the notion to historical contexts, considering how primary, secondary and metalinguistic sources can be used to reconstruct a communicative genre such as that of "paying a call".

${ }^{18}$ On German merchants in Italy see also Glück (2002: 246-250).
} 
the latest, such texts were a well-established tradition, in particular for Venetian clothmerchants trading with merchants from southern German cities (Pausch 1972, Blusch 1992). ${ }^{19}$ An example of haggling first given in McLelland (2004: 212-215) is provided below. (The original is German-Italian; I have replaced the Italian with my English translation.)

$\begin{array}{ll}\text { - Zaig her den parchant fon der chron. } & \text { - Show me the 'barchent }{ }^{20} \text { with the crown on it. } \\ \text { - Ich mag euch chain pösen zaigen, also } & \text { - I won't show you any bad one, so help me God. } \\ \text { helff mir Got. Ich bird in euch allsampt } & \text { I'll show them all to you and you take the one } \\ \text { zaigen und ir bert nemen den der euch } & \text { which pleases you best of all. And the one which } \\ \text { aller paz gefelt. Und den der euch aller } & \text { will be of most use to you to carry. }\end{array}$ nutz sey ze furn.

- Du sagst wol, do mogst nicht poz - You speak well, you cannot speak better. Do sagen. Hastu gueten falessi und gueten you have good 'falessi' and good 'bochasin'? bochasin?

- Han ich euch nicht gesagt? ich han - Haven'tI said so? I have the very best there is den aller pesten der in diser stat ist. in this town.

- Pring her! Lass in sehen!

- Bring it here! Let me see it!

[there follows a discussion of price] [...]

- Du peucz in zetewr. Ich mag in wol - You are offering it at too high a price. I can anderswo leichter haben. surely get it more easily elsewhere.

- Ez ist mir liebt ob er alz guet ist als - That's fine by me if it is as good as this here. der.

- Ich gelaub er sey noch pesser zwen - I think it is better still at two [ducats] per auff ein zentar. hundredweight.

\section{An extract from Cod. it. 261, cited in Höybye (1974: 174ff.)}

The tradition of modelling how to strike a bargain recurs throughout language manuals over the following centuries. In the following, I will consider this communicative genre across three related Dutch-English language manuals. Hillenius (1664) contains eleven dialogues (pp. 2-92); Sewel (1706) contais four unnumbered dialogues (Part II, pp. 2-29) and a further 41 numbered dialogues (pp. 97-288). Finally, James Teissier's revision of Sewel's text

\footnotetext{
${ }^{19}$ Hellgardt (1996) believes both sets of glosses are based on a much older tradition of using conversation in language teaching represented by the so-called Hermeneumata pseudodositheana of ca. 200 A.D., which contained models of Greek conversation for speakers of Latin. The earliest preserved exponent of the tradition dates from 1424, and we have evidence of a Venice language school run by a certain Master George of Nuremberg (Rossebastiano Bart 1983, 1984; Höybye 1956, 1964, 1974); a version of Italian-German language manuals attributed to Adam von Rottweil was printed in 1477 in Venice (ed. Giustiniani 1987).

${ }^{20}$ Barchent was a type of mixed cotton-linen cloth produced in Nuremberg. See the Nuremberg Stadtlexikon: http://online-service.nuernberg.de/stadtarchiv/rech.FAU?sid=6E6B18478\&dm=2\&auft=0, accessed May 2013.
} 
(Sewel \& Teissier 1788) contains 39 dialogues (pp. 248-434). The opening dialogues in Hillenius (1664) and Sewel (1706) are identical, save minor variations in wording; and Hillenius's Dialogue 5 To learne how to buy, and sell (1664: 13-21) is also virtually identical to Sewel's third dialogue, with the same title (Sewel 1706 Part II 6-18). Very little of Hillenius's dialogue material survives into Teissier's revisions of Sewel (1788), where a rather different dialogue headed Of buying and selling appears as Dialogue 6 (pp. 267-270). However, much of Sewel's new dialogue material is preserved in Teissier's revisions: Teissier's Dialogues 13 to 37 (pp. 296-416) repeat Dialogues 17-41 from Sewel (1706: part II, pp. 161-288). Thus, while the possibility of additional intermediaries, in particular between Hillenius and Sewel, cannot be ruled out, the three manuals stand in a clear tradition, with word-for-word correspondences across all three. Differences between them can be interpreted as significant.

The external structure of the genre of bargaining can be summarized as follows.

A seller has a commodity to sell. He or she is keen to sell, but for the highest possible price. No one sale is obligatory, but overall, he or she must make some sales. There is a minimum price, related to the cost price, below which the seller will not sell.

The buyer is keen to buy the commodity. Typically, he or she needs to buy the item, but either has a maximum price in mind or - in some cases, it seems - simply wishes to be confident that he or she is not paying over the odds. There is more than one location where the commodity can be purchased.

The communicative genre is composed of a number of predictable, stereotypical elements the examples in Table 2 are all taken from Sewel (1706, Part II, pp. 6-18, "To learn how to buy, and sell"), unless otherwise indicated. Many of the elements may be repeated.

\begin{tabular}{|c|c|}
\hline Element & Example \\
\hline 1. Asking a price & $\begin{array}{l}\text { How much shall I pay for th'Ell of this cloth? - Hoe veel } \\
\text { sal ick voor d'Elle van dit Laken betalen? }\end{array}$ \\
\hline 2. Naming a price & $\begin{array}{l}\text { You shall pay five Schillinghs for it - Gy sult 'er vyf } \\
\text { schellingen voor betalen }\end{array}$ \\
\hline 3. Buyer refuses price & It is a good deal too much - Het is veel te veel \\
\hline $\begin{array}{l}\text { 4. Invitation from seller to } \\
\text { buyer to suggest a price }\end{array}$ & $\begin{array}{l}\text { Offer me something-Bied my wat } \\
\text { Tell me what you will give for it - Seght my wat ghy 'er } \\
\text { voor geven wilt }\end{array}$ \\
\hline 5. Buyer offers a price & $\begin{array}{l}\text { I will give twenty and two styuvers for it, and not a doit } \\
\text { more - Ick sal 'er twee en twintig stuyvers voor geven, en } \\
\text { niet en duit meer }\end{array}$ \\
\hline
\end{tabular}




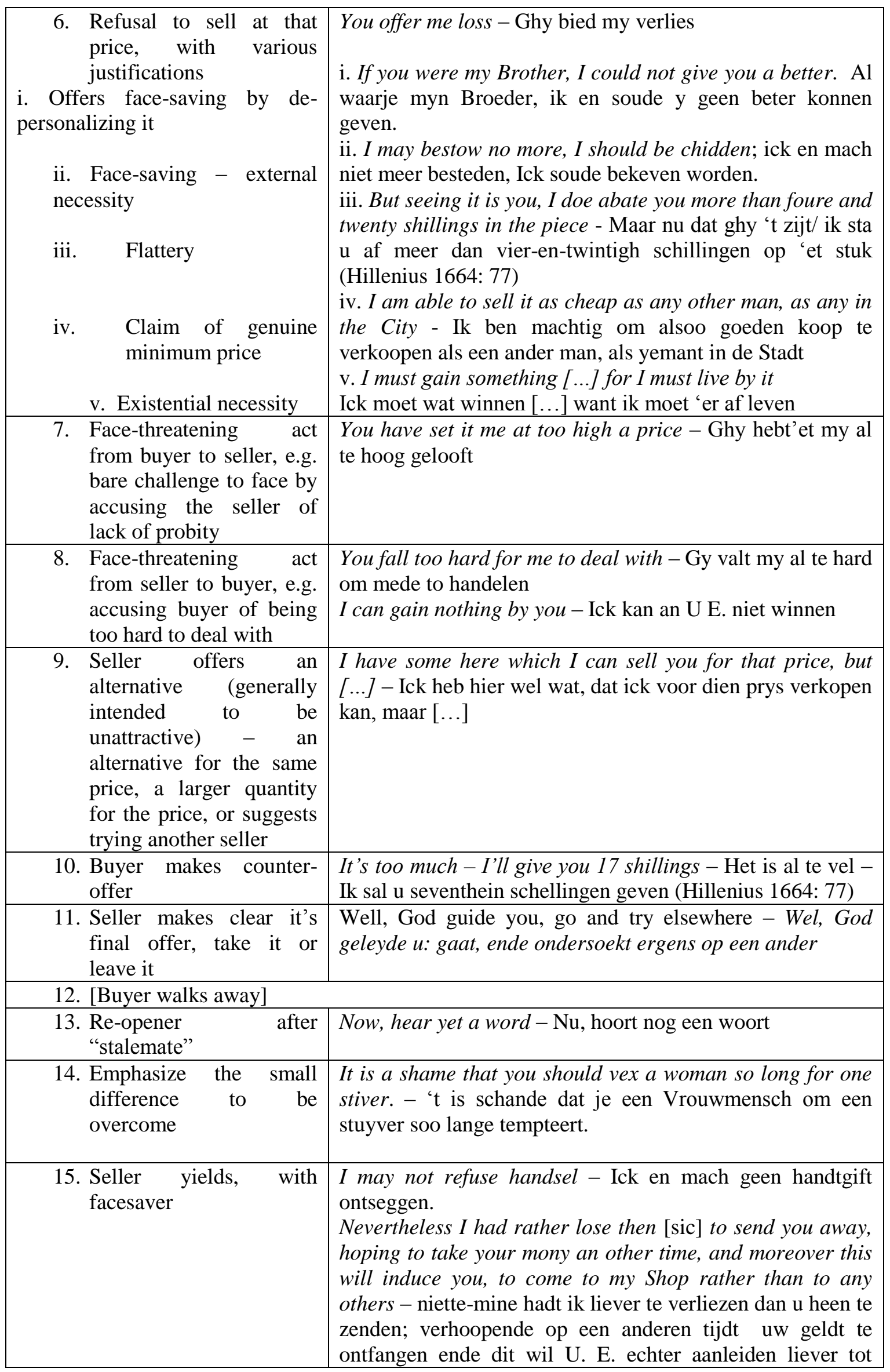


mijnen Winkel dan tot yemandt anders aan te komen.

(Hillenius 1664: 78)

Table 2: Elements of the communicative genre of bargaining (examples from Sewel 1706, Part II, pp. 6-18, unless otherwise indicated)

These exchanges take many turns - in the dialogue in Sewel (1706), there are 28 turns (14 from each participant), and that is before they even begin to argue about whether the coins the buyer hands over have been clipped or are in any other way invalid. A second example of haggling in Hillenius (1664: 76-78), in Dialogue 10, Discourses touching Merchandising, is less complex (and less naturalistic), but still takes 14 turns.

However, in the two eighteenth-century manuals, there seems to be a preference for less haggling. Although Sewel (1706) re-uses the two relevant Dialogues 5 and 10 from Hillenius, he also introduces many additional interactions where buyer and seller must agree a price, but where the haggling is less lengthy. The first of these examples comes in a dialogue that immediately following the first "of learning how to buy and sell" (Sewel 1706 Part II, 22-23). Here, a gentlewoman deals with the master's apprentice, who names a price for striped taffeta; although she retorts that she can buy it cheaper elsewhere, the apprentice does not waver, and the purchase of 25 ells is rapidly concluded in ten turns, with a reminder to the buyer that she can get a good price there in future.

B. Madam, it is of five gilders the ell.

B. Mejuffer, het is van vyf gulden de el.

Mrs. I can get it cheaper at another (place). Juf. Ick kan dat op een ander beter koop [sic] krygen.

B. That is the price at the word, you can not any where get it cheaper.

B. Dat is de prys met een woort. Ghy kunt Mrs. How many ells are there in that piece?

B. Just twenty-five. het nergens beter koop krygen.

Juf. Hoe veel ellen is 'er aan dat stuck?

Mrs. To how much doth that amount in all?

$B$. Net vyf en twintigh.

Juf. Hoe veel beloopt het alles?

B. To an hundred and five and twenty gilders. Mrs. There is your money, send it home by the porter.

B. Tot hondert en vyf-en-twintigh gulden.

Juf. Daar is u gelt, send het meet de kruyer t'huys.

(Sewel 1706 Part II, 22-23).

In the other dialogues of this kind in Sewel (1706), there are attempts at haggling too: over bills of exchange (p.44ff); over the hire of a coach (Part II, pp. 134-135), over the rent of two furnished rooms (pp. 141-142), and in three interactions to purchase, respectively, shoes (pp. 
166-168), cloth for a suit (pp. 190-91), and a hat (pp. 192-193). Yet the coachman, landlord, shoemaker and hatmaker all stand by their prices in the face of bald on-the-record facethreatening challenges by the would-be hirer or purchaser. Will you take no less? - No Sir, if you were my own brother, says the landlord (p. 142). The shoemaker likewise insists that his price is set despite the bald I do not believe you / Ik geloof $u$ niet of the purchaser (p. 168). In the case of the hat, the buyer admittedly begins with the face-threatening assertion 'Tis too dear / Dat is al te duur and makes a counter-offer, but already in his third turn says Tell me the lowest price / Zeg my de minste prys (p. 164), and then accepts the price. ${ }^{21}$ Only in the case of buying cloth does the haggling resemble the complexity of what we have seen in the earlier instances (which also concerned cloth), with a total of 22 turns, albeit short, drawing on the familiar repertoire of challenges (as to the quality of the merchandise) and justifications (the impossibility of beating the price elsewhere; claim to lose money compared to cost price):

The twenty-seventh Dialogue

Have you good cloth?

What cloth would you have?

Black cloth.

There is some.

How much is it a yard?

Thirty shillings a yard.

This is not thirty shillings cloth.

'Tis worth so much.

Is it some of the finest?

Yes, Sir.

I have will have none at that rate, 'tis too dear.

You cannot find cheaper in all the shops.

Will you sell it for five and twenty?

Upon my word I should lose by it; it cost me above eight and twenty.

It is impossible.

'Tis as true as you are here.

Make you but one word?

Have you said the utmost?

Yes, certainly.

Will you take eight and twenty?

I must gain something.

You shall have twenty nine.

Take it.
De zeven-en-twintighste t'Zamenspraak

Hebt gy goed Laken?

Wat voor Laken belief gy te hebben?

Zwarte Laken.

Zie daar.

Hoe veel is d'el.

D'el is dertig schellingen.

Dit is geen laken van dertig schellingen.

' $t$ is dat wel waardig.

Is het van 't mooiste?

Ja myn Heer.

Ik wil 't zo hoog van prys niet hebben, ' $t$ is my te dier.

Gy zult het in gene winkels beter koop krygen.

Wilt gy 'er vyf en twintig voor hebben?

Op myn word, ik zoud 'er aan verliezen; want het kost my self meer als achtentwintig.

Dat is onmoogelilk.

't Is so waar als gy hier zyt.

Houdt gy u zo aan een woord?

Hebt gy uyterste gezegd?

Ja, zekerlyk.

Wily gy achtentwintig hebben?

Ik moet immers iets winne.

Ik zal u negen en twintig geeven.

Wel neem het dan.

\footnotetext{
${ }^{21}$ No specific prices are mentioned - they are replaced with suspension points [...].
} 
Sewel (1706: 190-191)

Overall, Sewel's new dialogues in 1706 seem to model negotiations reflecting different norms in buying and selling compared to Hillenius (1664). Haggling is no longer represented as the normal way to buy and sell; there is an emerging expectation that prices are fixed. The reason for the survival of the old pattern of sustained hard bargaining in the case of cloth is unclear; perhaps simply because the dialogue comes from an older tradition; possibly buying cloth was considered a special case. Possibly the difference is one between wholesale dealing and retail (even if Sewel 1706 also contains numerous examples of commercial correspondence relevant to wholesale). The implied audience of Hillenius (1664) is trainee merchants, just as in the earliest such German-Italian manuals from the later Middle Ages. For example, the dialogues offer justifications for accepting handsel (i.e. making the first sale of the day) and for ensuring a good customer returns, and model how to check for counterfeit coins - in one exchange a coin is proved counterfeit by being nailed to a post. In the new material in Sewel (1706), we instead follow the experiences of a gentleman purchasing a suit, hat, and shoes. Further evidence that to haggle too meanly may be ungentlemanly comes from Dialogue 40 (Sewel 1706: 248-279), where a group of gentleman begin to haggle with a boatman over the price of carrying them to Greenwich for a day out. The boatman names his price of five shillings (a crown); one gentleman responds It is too much, you shall have four shillings / Dat is te veel, gy zult veer schellingen hebben (p. 251), but a companion intervenes: We must give them five shillings, they are honest men, they must get their living / Wy moeten haar vyf schellingen geven, 't zyn eeryke lieden, zy moeten 'er van leeven. Modelled here is a certain noblesse oblige, especially as the gentlemen - admittedly a little the worse for wear after a day of drinking - tip an additional shilling as drinkgeld (p. 277).

To summarize, the hard bargaining modelled in Hillenius (1664) is reminiscent of the late medieval Italian-German cloth-merchants bargaining; Sewel (1706) adds to this numerous dialogues accepting a fixed price; Sewel \& Teissier (1788) repeats the new 'fixed-price' material, and the original hard-bargaining dialogue of Hillenius (1664) is dropped. Overall, then, these three related Dutch-English texts reveal a change in the representation of the communicative genre of bargaining from 1664 to 1788 . Whether it is possible to identify a change more widely in a European communicative genre of transacting a sale would warrant further investigation by examining manuals for further language pairs. 


\subsection{Case study 3: Negative Politeness between guest and host}

While the case study above concerned the face-threatening acts in driving a hard bargain, my final example concerns threats to negative face (i.e., roughly, threats to an individual's freedom of action), ${ }^{22}$ and how they may be mitigated. Our case is the interaction in a dialogue where an Englishman invites a Dutchman to dinner (Sewel 1706, Dialogue 23: 174-180, corresponding to Dialogue 19 in Sewel \& Teissier 1788: 310-315). We have noted in Section 2 that in seventeenth- and eighteenth-century Europe politeness (and affected politesse) was a matter of explicit concern, with tension between the desire to be polite and the risk of being 'unnaturally' polite (as Gottsched viewed the use of Sie in some cases). ${ }^{23}$ Host-guest interactions are also interesting given recent research on the notions of hospitality in the period (though more in the history of mentalities than from a linguistic perspective, e.g. Still 2011, Mander 2012). The dialogue contains several instances of face-threatening acts and responses to them; my glossing of the exchanges appears in italics, within square brackets:

I. Sewel (1706: 174); identical in Sewel \& Teissier (1788:310)

A This is your place [threat to negative face of $B$, removing freedom of choice; $A$ takes pre-emptive redressive action through being indirect, rather than using an imperative. At the same time, $A$ is offering an honoured place to $B$, which imposes a debt on $B]$

B Sir, 'tis yours [refusal of the imposition, with its possible incurring of a debt to A] A Pray, without ceremonies, sit you down. [rejection of the refusal, re-statement of the face-threatening act as an imperative]

II. Sewel (1706: 178, 180); identical in Sewel \& Teissier (1788: 312, 314)

[Some discussion persuading $B$ to stay longer culminates in a bald on-the-record command: Sewel 1706: 178]

A. Do not go so soon. [A. notionally threatens $B$ 's negative face with an imperative, but more significant is the positive facework in making $B$ feel appreciated.]

B. 'Tis to obey you [i.e. that I stay longer]. [B casts the imposition back on A.]

A. You oblige us. [A. casts it back on to B once more.]

$B$. I would I were able to serve you. [B. hopes in future to return the debt incurred]

A. You are very obliging. [A. accepts this, and returns the imposition]

B. I never was so well treated. [B. compliments A.]

A. 'Tis but our ordinary [A. minimizes the compliment ${ }^{24}$

22 For nuanced discussion of the classic positions of Brown \& Levinson and Goffman (1967) in the light of recent studies, see Culpeper (2009: 24-31). See also Jucker \& Taavitsainen (2013, Chapter 7) for an introduction to positive and negative politeness in the context of historical pragmatics.

${ }^{23}$ See also Jucker (2011) on the changing weights ascribed to negative and positive politeness in the history of English.

${ }^{24}$ Compare also a similar minimizing of the compliment offered here: This is good wine - 'Tis but indifferent (Sewel 1706: 175). 


\section{$[\ldots]$}

B. I give you many thanks for your good entertainment. You overcome me with your civilities. [B. seeks to redress the imposition of debt.]

A. I am wholly yours. [A. continues to impose the debt.]

B. I find well the occasions to trouble you, but not to serve you. [B. acknowledges the imposition.]

Such exchanges are on the border between politeness and verbal jousting, as the interlocutors virtually compete in resisting the imposition placed on them by the other. One is reminded of the finding of Bax \& Streekstra (2003), on the basis of their analysis of seventeenth-century Dutch correspondence, that "negatively polite ostentation is by and large a ritual affair, particularly since the use of subservient phrases and other expressions according to the humiliative mode is generally a game, rather than earnestly paying deference. [...] Early modern society was quite preoccupied with various genres of 'deceit', artistic and otherwise, and took much pleasure in the witty exploitation of multiple meaning design, also when it concerned doing the civil thing" (Bax \& Streekstra 2003: 303). The same seems to be true, too, of the eighteenth-century exchanges modelled here.

We find another example of such playfulness - or more accurately, of the unmasking of the game as a game - in a dialogue where gentlemen criticize each other for "standing on ceremony" and "making too many compliments" in their eagerness to ensure they are not the first to step into a boat ahead of their fellows (Sewel 1706: 253-254, corresponding to Sewel \& Teissier 385-386).

C. Come then, Gentlemen, let us step into the Boat.

D. Step in first, we will follow you.

A. Without ceremony, Gentlemen, let him follow me that loves me.

B. What needs so many compliments; For my part I never use any; I take my place by you, for you keep the Bottles.

C. Sir, I intreat you not to let me commit any incivility.

D. Sir, I will not go before you, I know well the respect that is due to you.

C. But, Sir, you will laugh at me, we will stay here then till tomorrow.

A. I must confess, Gentlemen, you are very ceremonious.

B. Come, come Gentleman, let us make haste, what needs so many
C. Komt, dan, Heeren, laat ons in de SChuyt treeden.

D. Stap eerst in, wy zullen u volgen.

A. Zonder Ceremonien Heeren, die my lief heft mag my volgen.

B. Waar toe zo veel Complementen? Ik voor my, gebruik ze nooit: Ik ga by u zitten, want gy hebt de Bottels by $u$.

C. Myn Heer, ik bid u, laat my geen onheusheyd began.

D. Myn Heer, ik wil voor u niet ingaan, ik weet zeer wel, wat eerbiedigheyt ik u schuldig ben.

C. Maar myn Heer, gy lacht om my, zo doende zullen wy hier wel tot Morgen stan.

A. Ik moet bekennen Heeren, dat gy vol Ceremonien zyt.

B. Kom, kom, Heeren, laat ons wat haast maken, waar toe zo veel Ceremonien onder 
ceremonies among friends?

D. I beseech you, Sir, let us not make these Gentlemen stay.

C. Sir, I had rather commit an incivility, than to disobey you. vrienden?

D. Ik bid u myn Heer, laat ons deeze Heeren niet doen wachten.

C. Myn Heer, ik wil liever een onbeleefdheyd begaan, dan u ongehoorzaam syn.

\section{Sewel (1706: 253-254)}

Another instances can be found in Sewel's $25^{\text {th }}$ dialogue (Sewel 1706: 186), where two gentlemen seek to pay for the other, until one exclaims, "We are not in France", presumably an allusion to the idea that excessive politeness is a French habit in its origin; and in the rejection of excessive apologizing in an exchange between a lady and gentleman (Sewel 1706: 187-88). In such cases, model dialogues can become themselves metalinguistic commentary on pragmatics. $^{25}$

\section{Conclusion and outlook}

Notwithstanding the methodological risks noted in Section 1., I hope here to have demonstrated the potential of foreign language learning materials to illuminate both the history and historiography of pragmatics. First, metalinguistic statements can contribute explicitly to the historiography of linguistics and the history of language change, as in the case of German conventions for forms of address. Second, we may examine how linguistic behaviour is modelled in dialogues and so trace evidence for changes in pragmatics over time, as explored here in the apparent changes to the unwritten rules governing the communicative genre of bargaining. Thirdly, dialogues may encode metalinguistic commentary, for example on excessive politeness, exposed in Sewel (1706) and Sewel \& Teissier (1788) as a game.

In a further step, these bilingual dialogues - adapted and recycled, with often changing language pairs, including French, Spanish and Italian as well as the Dutch, German and English cases considered here - could be valuable sources for tracing the exchange of cultural knowledge and cultural practices, including pragmatics, across early modern and Enlightenment Europe. It would also be fruitful to compare the pragmatic information

\footnotetext{
${ }^{25}$ In a variation on the game, in Dialogue 44, a brother claims to be complimenting his sister on having invited such a charming lady to dinner; the compliment is of course directed at the guest. Here complimenting becomes intertwined with ritualized love-making (Sewel 1706: 284-85), another topic which is frequent in a number of $18^{\text {th }}$-century language learning manuals.
} 
contained in such language manuals for non-native speakers not just with native grammars of the time (as here in Section 2) but also with manuals intended for competent native-speakers: civility manuals such as Courtin's Nouveau traité de la civilité (1672), swiftly translated also into English, German and Italian (see Mander 2015), titularies, epistolographies, and rhetorics (such as Sattler 1604 and its successors; see Till 2004 for the history of rhetoric in German), and, indeed, merchants' guides (e.g. Savary 1713). For the present paper, however, I have limited myself to the first step of exploring the potential of manuals for non-native speakers.

Finally, this article has offered a 'proof of principle' for using historical language learning materials to examine speech acts (e.g. complimenting) but also, on a larger scale, communicative genres (e.g. bargaining). We must continue to exploit such sources to help provide a historical perspective on core topics in contemporary pragmatics: to examine apologies, complaints, or the expression of epistemic modality, for example; but also to examine communicative genres such as patient-doctor interactions, an obvious candidate because they are not only the focus of current research (e.g. Cordella 2004), but were also frequently modelled in language learning dialogues.

\section{References}

\subsection{Primary sources}

[Aedler, Martin] [anon.]. 1680. The Hig [sic] Dutch Minerva [...]. London: Printed for the author. Facsimile reprint Menston, England: Scolar Press, 1972.

Adelung, Johann Christoph. 1782. Umständliches Lehrgebäude der Deutschen Sprache [...]. Leipzig: verlegts Johann Gottlob Immanuel Breitkopf.

Bachmair, John James. 1751, 1752, 1771. A complete German grammar [...]. 1st ed. London: [n.p.]; 2nd ed. London: for Andr. Linde, etc.; 3rd ed. ("greatly altered and improved") London : Printed for G. Keith, B. Law, E. and C. Dilly, and Robinson and Roberts.

Beiler, Benedictus. 1731. A New German Grammar. Whereby an Englishman may easily Attain to the Knowledge of the German Language, Especially Useful for Merchants and Travellers. London: J. Downing for the Author.

Courtin, Antoine de. 1672a. Nouveau Traité De La Civilité Qui Se Pratique En France, Parmi Les Honnestes Gens. $2^{\text {nd }}$ ed. Amsterdam: Jaques Le Jeune.

Courtin, Antoine de. 1672b. The Rules of Civility; or, Certain Ways of Deportment Observed Amongst All Persons of Quality Upon Several Occasions. Newly revised and much enlarged. ed. London: Printed for R. Chiswell, T. Sawbridge, G. Wells and R. Bently.

Courville, Antonio. 1728. Explicación de la gramática francesa. Madrid.

Crabb, George. 1800. A Complete Introduction to the Knowledge of the German Language; or, a Translation from Adelung: Arranged and Adapted to the English Learner. London: Printed for the author, by C. Whittingham. 
Gottsched, Johann Christoph. 1748. Grundlegung Der Deutschen Sprachkunst [...]. Leipzig: Verlegts Bernh. Christoph Breitkopf.

Hillenius, Francois. Den Engelschen ende Ne'erduitschen Onderrichter [...]. Rotterdam Bastiaan Wagens, 1664.

Kramer, Johann Matthias. 1746. Kurzverfasste Anleitung zur englischen Sprache [...] Nach Der ... Lehrart ... Wilhelm Sewels. Hamburg: in der Hertelischen Handlung.

Lediard, Thomas. 1725. Grammatica Anglicana Critica. Hamburg: printed for the author.

Sattler, Johann Rudolph. 1604. Teutsche Rhetorik, Titular und Epistelbüchlein. Basle: Ludwig König.

Savary, Jacques, and Jacques Savary des Brûlons. 1713. Le Parfait Negociant [...]. 7th ed. Paris: Chez M. Guignardet et C. Robustel.

Schottelius, Justus Georg. 1663. Ausführliche Arbeit von der Teutschen Haubtsprache, Braunschweig: Zilliger. Facsimile ed. Tübingen: Niemeyer, 1967.

Sewel, Wilhelm. 1705, 1706. A Compendious Guide to the English Language. 1705. Second ed. 1706. Amsterdam: printed for the widdow [sic] of Stephen Swart.

Sewel, Willem. 1708a. Nederduytsche Spraakkonst. Amsterdam: Assuerus Lansvelt.

Sewel, William. 1708b. A Large Dictionary English and Dutch, in Two Parts [...]. T' Amsterdam: by de weduwe van Steven Swart, by de Beurs.

Sewel, William, revised by James Teissier. $1788 \mathrm{~W}$. Sewel's Compendious Guide to the LowDutch Language: Partly Enlarged and Improv'd by James Teissier. The fourth edition. ed. Amsterdam: by W. Vermandel.

Stieler, Kaspar. 1691. Der Teutschen Sprache Stammbaum und Fortwachs [...]. Nuremberg: Johann Hoffmann. Rpt. with an afterword by Stefan Sonderegger. 3 vols. Munich: Kösel, 1968.

Veneroni, Giovanni. 1678. Maître italien. Paris.

Veneroni, Giovanni, and Thomas Uvedale. 1728. The Italian Master: Or, the Easiest and Best Method for Attaining That Language: Revised, Corrected and Enlarged. Done into Engl. By Mr. Uvedale. $2^{\text {nd }}$ ed., to which is added, a dictionary, tr. by E. Martin. ed. London.

Wendeborn, Gebhard Friedrich August. 1774. The Elements of German Grammar. London: printed for C. Heydinger.

Williamson, H.R. 1947. Teach Yourself Chinese. London: Hodder \& Stoughton for the English Universities Press.

\subsection{Research literature}

Bax, Marcel. 2001. Historical Frame Analysis: Hoaxing and Make-Believe in a SeventeenthCentury Dutch Play Journal of Historical Pragmatics 2: 33-67.

Bax, Marcel and Dániel Z. Kádár, Eds. 2011. Understanding Historical (Im)Politeness (Special Issue of the Journal of Historical Pragmatics, 12: 1/2).

Bax, Marcel, and Nanne Streekstra. 2003. "Civil Rites: Ritual Politeness in Early Modern Dutch Letter-Writing." Journal of Historical Pragmatics 4(2) (special issue: Ritual Language Behaviour): 303-325.

Besch, Werner. 1996. Duzen, Siezen, Titulieren : Zur Anrede Im Deutschen Heute Und Gestern. Göttingen: Vandenhoeck \& Ruprecht.

Blusch, Martina, ed. 1992. Ein italienisch-deutsches Sprachlehrbuch des 15. Jahrhunderts. Edition der Handschrift Universitätsbibliothek Heidelberg Pal. Ger. 657 und räumlich-zeitliche Einordnung des deutschen Textes. Frankfurt: Lang.

Brown, Penelope, and Stephen C. Levinson. 1987. Politeness. Some universals in language usage. Cambridge: CUP. 
Bruña Cuevas, Manuel. Forthcoming. "Recycled materials: adapting an Italian manual to teach French in eighteenth-century Spain Veneroni en Espagne: 1'Explicación de la gramática francesa (Madrid, 1728) de Courville." To appear in: The History of Language TEachign and Learning, ed. Nicola McLelland \& Richard Smith. London: Maney/MHRA.

Carr, Charles. 1935. German grammars in England in the nineteenth century. Modern Language Review 30: 483-501.

Cordella, Marisa. 2004. The Dynamic Consultation. A Discourse Analytical Study of DoctorPatient Communication. Amsterdam: Benjamims.

Culpeper, Jonathan. 2009. Impoliteness: Using and Understanding the Language of Offence. Cambridge: CUP.

Durrell, Martin. 2002. Hammer's German grammar and usage. London: Arnold.

Gardt, Andreas. 1999. Geschichte der Sprachwissenschaft in Deutschland. Vom Mittelalter bis ins 20. Jahrhundert. Berlin: de Gruyter.

Giustiniani, Vito R. 1987. Adam Von Rottweil, Deutsch-Italienischer Sprachführer. Tübingen: Gunter Narr.

Glück, Helmut. 2006. "Anredekonventionen im Deutschen: ein geschichtlicher Überblick." In: Dialogic language use, ed. Irma Taavitsainen et al., 159-171. Helsinki: Société Néophilologique.

Glück, Helmut. 2002. Deutsch als Fremdsprache in Europa vom Mittelalter bis zur Barockzeit. Berlin: de Gruyter.

Glück, Helmut. 2013. Die Fremdsprache Deutsch im Zeitalter von Aufklärung, Klassik und Romantik. Wiesbaden: Harrassowitz.

Goffman, Erving. 1967. Interaction ritual: essays on face-to-face behaviour. New York: Doubleday.

Günthner, Susanne, and Hubert Knoblauch. 1995. "Culturally Patterned Speaking Practices. The Analysis of Communicative Genres." Pragmatics 5(1): 1-32.

Guthke, Karl. 2011. Deutsche Literatur aus zweiter Hand: Englische Lehr-und Lesebücher in der Goethezeit. Jahrbuch des Freien Deutschen Hochstifts 2011: 163-237.

Hall, David J. 2004. "Sewel, Willem (1653-1720)." In Oxford Dictionary of National Biography. Oxford: Oxford University Press. [Http://Www.Oxforddnb.Com/View/Article/25139, Accessed 5 Dec 2014].

Hellgardt, Ernst. 1996. "Mehrsprachigkeit im Karolingerreich". Beiträge zur Geschichte der deutschen Sprache und Literatur 118: 1-48.

Höybye, Poul. 1956. "Meister Jörg fra Nürnberg. Troek af Middelalderens Sprogundervisning." In Festskrift til Christen Möller, ed. by Louis Hammerich, Max Kjaer-Hansen and Peter Skautrup, 205-221. Copenhagen: Borgen.

Höybye, Poul. 1964, 1974. "Glossari italiano-tedeschi del Quattrocento I, II." Studi di Filologia Italiana 22: 167-204, 32: 143-203.

Hüllen, Werner. 2005. Kleine Geschichte des Fremdsprachenlernens. Berlin: Erich Schmidt Verlag.

Jucker, Andreas H. 2011. "Positive and Negative Face as Descriptive Categories in the History of English " Journal of Historical Pragmatics 12(1-2): 178-197.

Jucker, Andreas H., and Irma Taavitsainen. 2013. English Historical Pragmatics. Edinburgh: Edinbrugh University Press.

Jucker, Andreas H., Gerd Fritz and Franz Lebsanft, eds. 1999. Historical Dialogue Analysis. Roots and Traditions in the Study of the Romance Languages, German and English. Amsterdam: Benjamins. 
Klippel, Friederike. 1994. Englischlernen im 18. Und 19. Jahrhundert. Die Geschichte der Lehrbücher und Unterrichtsmethoden. Münster: Nodus.

Langer, Nils. 2002. "On the importance of Foreign Language Grammars for a History of Standard German." In Standardization: Studies from the Germanic Languages, ed. by Andrew R. Linn and Nicola McLelland, 67-82. Amsterdam: Benjamins.

Langer, Nils. 2004. "Frühe Fremdsprachengrammatiken als Vermittlerinnen der Standardsprache." In Sprachwandel und Gesellschaftswandel: Wurzeln des heutigen Deutsch, ed. by Klaus J. Mattheier and Haruo Nitta, 223-243. Munich: iudicium.

Linke, Angelika. 1996. Sprachkultur und Bürgertum. Zur Mentalitätsgeschichte des 19. Jahrhunderts. Stuttgart: Metzler.

Linke, Angelika. 1988. "Die Kunst Der 'Guten Unterhaltung': Bürgertum Und Gesprächskultur Im 19. Jahrhundert." Zeitschrift für Germanistische Linguistik 16: 123-144.

Linke, Angelika. 2007. "Communicative Genres as Categories in a Socio-Cultural History of Communication." In Germanic Language Histories 'from Below' (1700-2000), ed. by Stephan Elspaß et al., 473-493. Berlin: de Gruyter.

Loonen, Pieter. 1991. For to learne to buye and sell : learning English in the Low Dutch area between 1500 and 1800: a critical survey. Amsterdam: AUP-Holland University Press.

Losfeld, Christophe, and Alain Montandon. 2011. Politesse, Morale et Construction Sociale: Pour une Histoire des Traités de Comportements (1670-1788). Paris: Honoré Champion Éditeur.

Mander, Jenny. 2012. "Politeness to Strangers: The Mark or Mask of Civility?" In Evocations of Eloquence, ed. by Nicholas Hammond and Michael Moriarty, 299-314. Frankfurt: Lang.

McLelland, Nicola. 2004. Dialogue and German Language Learning in the Renaissance. In: Printed Voices. The Renaissance Culture of Dialogue, ed. D. Heitsch and J.-F. Vallée, 206-225. Toronto: University of Toronto Press.

McLelland, Nicola. 2008. "Approaches to the semantics and syntax of the adverb in German foreign language grammars." Beiträge zur Geschichte der Sprachwissenschaft 18(1): $37-58$.

McLelland, Nicola. 2011. J.G. Schottelius's Ausführliche Arbeit von der Teutschen Haubtsprache (1663) and its Place in Early Modern European Vernacular Language Study. Oxford: Blackwell.

McLelland, Nicola. 2015a. "Teach Yourself Chinese - how? The history of Chinese selfinstruction manuals for English speakers, 1900-2010." Journal of the Chinese Language Teachers Association 50(2): 109-152.

McLelland, Nicola. 2015b. German Through English Eyes. A History of Language Teaching and Learning in Britain, 1500-2000. Wiesbaden: Harrassowitz.

McLelland, Nicola, and Richard Smith, eds. 2014. Building the History of Modern Language Learning. Special Issue of Language \& History, 57(1), with an Introduction by the editors.

Noordegraaf, Jan, and Frank Vonk. 1993. Five Hundred Years of Foreign Language Teaching in the Netherlands. Amsterdam / Münster: Stichting Neerlandistik / Nodus.

Pausch, Oskar. 1972. Das älteste italienisch-deutsche Sprachbuch. Eine Überlieferung aus dem Jahre 1424 nach Georg von Nürnberg. Vienna: Böhlhaus.

Polenz, Peter von. 1999. Deutsche Sprachgeschichte Vom Spätmittelalter Bis Zur Gegenwart. Vol. Iii 19. Und 20. Jahrhundert. Berlin: de Gruyter. 
Radtke, Edgar. 1994. Gesprochenes Französisch und Sprachgeschichte: zur Rekonstruktion der Gesprächskonstitution in Dialogen französischer Sprachlehrbücher des 17. Jahrhunderts unter besonderer Berücksichtigung der italienischen Adaptionen. Tübingen: Niemeyer.

Rossebastiano Bart, Alda, ed. 1983. Vocabulari Veneto-Tedeschi del Secolo XV. Torino: L'artistica Savigliano.

Rossebastiano Bart, Alda. 1984. I Dialoghi di Giorgio da Norimberga: Redazione Veneziane, Versione Toscana, Adattemento Padavano. Savigliano: L'artistica Savigliano.

Rutten, Gijsbert and Rik Vosters. 2011. Een Nieuwe Nederduitse Spraakkunst. Taalnormen en Schrijfpraktiken in de Zuidelijke Nederlande in de Achttiende Eeuw. Brussels: VUB Press.

Salmon, Vivian. 1992. "Anglo-Dutch Linguistic Scholarship: A Survey of SeventeenthCentury Achievements." In The History of Linguistics in the Low Countries, ed. by Jan Noordegraaf, Kees Versteegh and Konrad Koerner, 129-153. Amsterdam: Benjamins.

Salverda, Reinier. 2004. "A Hundred Years of Explaining the Dutch Language to Speakers of English, from Hoogvliet's Elements (1908) to the Present." In Thesaurus Polyglottus et Flores Quadrilingues. Festschrift für Stanislaw Predota zum 60. Geburtstag, ed. by Stefan Kiedron and Agata Kowalska-Szubert, 357-382. Wroclaw: Oficyna Wydawnicza ATUT.

Scheurweghs, Gustave. 1960. "English Grammars in Dutch and Dutch Grammars in English in the Netherlands before 1800." English Studies 41: 129-67.

Still, Judith. 2011. Enlightenment Hospitality: Cannibals, Harems and Adoption. Oxford: Voltaire Foundation.

Till, Dietmar. 2004. Transformationen Der Rhetorik: Untersuchungen Zum Wandel Der Rhetoriktheorie Im 17. Und 18. Jahrhundert. Tübingen: Niemeyer, 2004.

Tisala, Seija. 2004. Power and Politeness: Languages and Salutation Formulas in Correspondence between Sweden and the German Hanse. Journal of Historical Pragmatics 5: 193-206.

Turcot, Lauren. 2011. "Civilité, Politesse et Galanterie au 18e Siècle. Sur: Christophe Losfeld, Politesse, Morale et Construction Sociale. Pour une Histoire des Traités de Comportements (1670-1788), Paris, Honoré Champion." Acta Fabula 12(4): Http://Www.Fabula.Org/Revue/Document6278.Php\#Ftn4.

Unzeitig, Monika, Nine Miedema, and Franz Hundschnurscher, eds. 2011. Redeszenen in der mittelalterlichen Großepik. Berlin: Akademie Verlag.

Van der Lubbe, Fredericka. 2007. Martin Aedler and the High Dutch Minerva. The First German Grammar for the English. Frankfurt: Lang.

Van der Lubbe, Fredericka. 2008. Constructing Germany: The German nation in AngloGerman grammars of the eighteenth century. In: Anglo-German linguistic relations, ed. Falco Pfalzgraf and Felicity Rash, 63-72. Frankfurt: Lang.

van der Wal, Marijke. 1992. Geschiedenis Van Het Nederlands. Utrecht: AULA.

Verbaan, Eddy, and Roel Vismans. 2010. "Modern Dutch Studies. Peter King en de Opkomst van 'Area Studies'." In Neerlandistiek in Europa. Bijdragen tot de Geschiedenis van de Extramurale Neerlandistiek Buiten Nederland en Vlaanderen, ed. by Matthias Hüning et al., 333-347. Münster: Waxmann.

Vorlat, Emma. 1969. "Francois Hillenius's Korte ende Noodwendige Regulen (1664): Dependence and Originality." English Studies 50: 1-10.

Whitt, Richard J. 2015. "Evidentiality in Early Modern German." Journal of Historical Pragmatics 17(1): tbc. 
